\title{
PERFORMANCE ANALYSIS OF INDIRECT ROTOR FIELD ORIENTATED CONTROL FOR FIVE PHASE INDUCTION MOTOR DRIVE
}

\author{
Mahmoud M. Elkholy* ; Zakaria M.S. Elbarbary** \\ *Electrical Power and Machines Department, Faculty of Engineering, Zagazig University, \\ Zagazig, Egypt \\ **Department of Electrical Engineering, Faculty of Engineering, Kafrelsheikh University, EGYPT \\ Electrical Engineering Department, Faculty of Engineering, King Khalid University, Abha, Saudi \\ Arabia \\ *Corresponding Author : Mahmoud Elkholy (melkholy71@yahoo.com)
}

\begin{abstract}
This paper proposes a new topology of five-phase inverter with reduced number of switches fed coil with indirect rotor field oriented five-phase induction motor. It employs only eight IGBT switches performing a five-phase inverter. The reduction of the number of power switches from ten to eight reduces the cost, volume-compactness and reliability of five-phase induction motor drive systems. Simulation of the proposed drive system is developed using the Matlab/Simulink package and the results are analyzed to verify the effectiveness at different operating conditions. Comparison between performance of the five-phase induction motor under classical ten-switch inverter and the new topology, at the same operation conditions, has been illustrated. The proposed system gives similar operations as the classical ten-switch inverter for a certain range of motor speed and load torque. The DC voltage of the proposed inverter must be compensated to a higher value for achieving the same performance of classical ten-switch inverter in all ranges of motor speed and load torque.

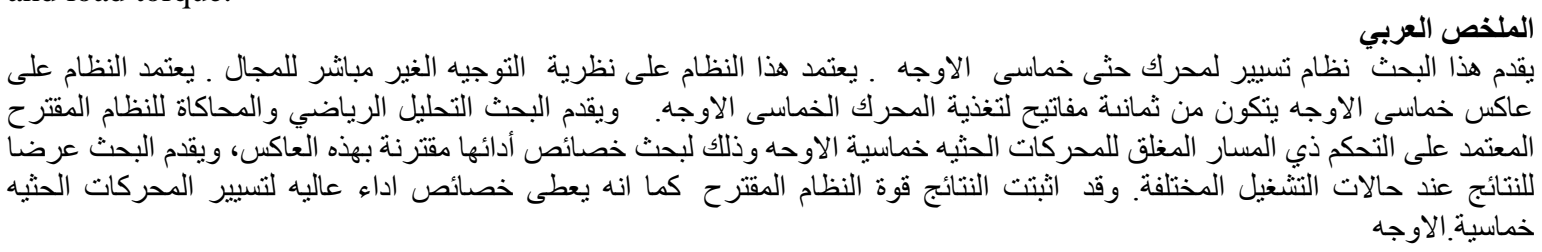

Keyword: Five phase induction motor, Field oriented control, Ten-switch inverter, Eight-switch inverter

\section{INTRODUCTION}

Multiphase drives have several advantages over conventional three-phase drives such as: reducing motor phase current without increasing the phase voltage, increasing the frequency and reducing the amplitude of torque pulsations, increasing the torque / RMS ampere for the same machine volume [1-2]. With the advancement in power electronics, interest in multi-phase machine has been increased tremendously as high power electronic devices are used as a switch in voltage source inverter (VSI). To increase power system level, two approaches are used; the first one is the use of multilevel inverters supplying three-phase machines [3-4]. The second approach is multi-leg inverters fed multiphase machines [5-6]. It is noted that the similarity between two approaches ,in multilevel inverter the additional switching devices increase the number of voltage levels, while in the multi leg inverter, the additional number of switching devices increases the number of phases.
The performance under faulty conditions in voltage source inverter or in motor windings is one of advantages of multi phase motor [7-10]. Two techniques are used in five phase inverter, one, is the carrier based pulse width modulation (PWM) and the other is the space vector modulation (SVM) [11-14].

This paper study a new inverter topology to fed indirect rotor field oriented five phase induction motor drive system. This inverter topology consists of eight switches instead of ten switches, two switches used for every phase and the fifth phase connected to the midpoint of dc-link capacitor. This topology of the inverter introduces many advantages compared to traditional ten switch inverter, such as, compactness, simplicity, low cost, and more reliable. To ensure the validity of drive system with the proposed topology, a simulations of the system is made using Simulink/MATLAB. Simulation results are carried out at different operating conditions and show that the performance characteristics are 
similar in both cases of classical ten switch inverter and proposed eight switch inverter for a certain range of speed and load torque. To have the same performance for all range of speed and load torque the DC voltage of proposed inverter must be increased.

\section{MATHEMATICAL MODEL of 5- PHASE INDUCTION MOTOR}

Squirrel-cage five-phase induction motor is represented in its $\mathrm{d}-\mathrm{q}$ synchronous reference frame. The winding axes of five-stator winding are displaced by 72 electrical degrees. In this analysis the air gap is uniform and the windings are sinusoidal distributed around the air gap magnetic saturation and core losses are neglected. As for the three-phase induction motor, where the well-known $\mathrm{d}-\mathrm{q}$ rotating reference is used in analysis and control. A d-q reference frame is also used for the five-phase induction motor. The fivephase induction machine can be modeled with the following voltage equations in synchronous reference frame [15-16].

The q-d stator and referred rotor voltages are given by:

$$
\begin{gathered}
V_{q s}=R_{s} I_{q s}+\frac{d \psi_{q s}}{d t}+\omega_{e} \psi_{d s} \\
V_{d s}=R_{s} I_{d s}+\frac{d \psi_{d s}}{d t}-\omega_{e} \psi_{q s} \\
0=R_{r} I_{q r}+\frac{d \psi_{q r}}{d t}+\left(\omega_{e}-\omega_{r}\right) \psi_{d r} \\
0=R_{r} I_{d r}+\frac{d \psi_{d r}}{d t}-\left(\omega_{e}-\omega_{r}\right) \psi_{q r}
\end{gathered}
$$

Where, $V_{q s}, V_{d s}, \psi_{q s}, \psi_{d s}$ are the $\mathrm{q}$ and $\mathrm{d}$ components of stator voltage and flux. $I_{q s}, I_{d s}, I_{q r}$ and $I_{d r}$ are the $\mathrm{q}$ and $\mathrm{d}$ component of stator and referred rotor currents. $R_{s}$ and $R_{r}$ are stator and referred rotor windings resistance. $\omega_{\mathrm{e}}$ is the speed of stator field in elec $\mathrm{rad} / \mathrm{s}$. $\omega_{\mathrm{r}}$ is the rotor speed in elec $\mathrm{rad} / \mathrm{s}$.

For the stationary reference frame $\omega_{e}=0$, substitute into Eqs. (1) to (4) yields:

$$
\begin{gathered}
V_{q s}=R_{s} i_{q s}+\frac{d \psi_{q s}}{d t} \\
V_{d s}=R_{s} i_{d s}+\frac{d \psi_{d s}}{d t} \\
0=R_{r} i_{q r}+\frac{d \psi_{q r}}{d t}-\omega_{r} \psi_{d r} \\
0=R_{r} i_{d r}+\frac{d \psi_{d r}}{d t}+\omega_{r} \psi_{q r}
\end{gathered}
$$

The q-d stator flux linkage are given by:

$$
\psi_{q s}=\left(L_{l s}+L_{m}\right) i_{q s}+L_{m} i_{q r}
$$

$$
\psi_{d s}=\left(L_{l s}+L_{m}\right) i_{d s}+L_{m} i_{d r}
$$

Where; $\mathrm{L}_{\mathrm{ls}}$ and $\mathrm{L}_{\mathrm{m}}$ are the stator leakage and mutual inductance.

The q-d referred rotor flux linkage are given by:

$$
\begin{gathered}
\psi_{q r}=\left(L_{l r}+L_{m}\right) i_{q r}+L_{m} i_{q s} \\
\psi_{d r}=\left(L_{l r}+L_{m}\right) i_{d r}+L_{m} i_{d s}
\end{gathered}
$$

Where; $\mathrm{L}_{l r}$ is the rotor leakage inductance.

The electromagnetic torque is given by:

$$
T_{e}=\frac{5}{2} \frac{P}{2} \frac{L_{m}}{L_{r}}\left(\psi_{d r} i_{q s}-\psi_{q r} i_{d s}\right)
$$

The rotor dynamic equation is:

$$
T_{e}-T_{L}=J \frac{d \omega_{r}}{d t}+B \omega
$$

Where; $P$ is the number of poles, $J$ is the moment of inertia $\mathrm{kg} \cdot \mathrm{m}^{2}, B$ is the friction coefficient N.m.s/rad.

To achieve indirect rotor field oriented control of five phase induction motor the component $\psi_{q r}$ must equals zero. In this case, the reference value of quadrature current component in synchronous rotating frame is given by:

$$
I_{q s}^{e *}=\frac{2}{5} \frac{2}{P} \frac{L_{r}}{L_{m}} \frac{\left(\omega^{*}-\omega_{r}\right)\left(K_{p}+\frac{K_{i}}{S}\right)}{\psi_{d r}^{*}}
$$

The reference value of direct current component in synchronous rotating frame is given as:

$$
I_{d s}^{e *}=\frac{1}{L_{m}}\left(1+\frac{L_{r}}{R_{r}} p\right) \psi_{d r}^{*}
$$

The angular slip frequency command $\left(\omega_{s l}^{*}\right)$ is:

$$
\omega_{s l}=\frac{R_{r} L_{m}}{L_{r}} \frac{I_{q s}^{e *}}{\psi_{d r}^{*}}=\frac{L_{m}}{\tau_{r}} \frac{I_{q s}^{e *}}{\psi_{d r}^{*}}
$$

Where; $\tau_{r}=\frac{L_{r}}{R_{r}}$ is the rotor time constant.

The angular frequency can be calculated as:

$$
\begin{gathered}
\omega_{\mathrm{e}}=\omega_{\mathrm{sl}}+\omega_{\mathrm{r}} \\
\theta_{e}=\int \omega_{e} d t
\end{gathered}
$$

The reference currents can be given as:

$$
\left\{\begin{array}{c}
i_{a}^{s *}=i_{q s}^{*} \cos \left(\theta_{e}\right)+i_{d s}^{*} \sin \left(\theta_{e}\right) \\
i_{b}^{s *}=i_{q s}^{*} \cos \left(\theta_{e}-\frac{2 \pi}{5}\right)+i_{d s}^{*} \sin \left(\theta_{e}-\frac{2 \pi}{5}\right) \\
i_{c}^{s *}=i_{q s}^{*} \cos \left(\theta_{e}-\frac{4 \pi}{5}\right)+i_{d s}^{*} \sin \left(\theta_{e}-\frac{4 \pi}{5}\right) \\
i_{d}^{s *}=i_{q s}^{*} \cos \left(\theta_{e}+\frac{4 \pi}{5}\right)+i_{d s}^{*} \sin \left(\theta_{e}+\frac{4 \pi}{5}\right) \\
i_{e}^{s *}=i_{q s}^{*} \cos \left(\theta_{e}+\frac{2 \pi}{5}\right)+i_{d s}^{*} \sin \left(\theta_{e}+\frac{2 \pi}{5}\right)
\end{array}\right\}
$$

With Field oriented control, the motor torque is given by:

$$
\mathrm{T}_{\mathrm{e}}=\frac{5}{2} \frac{\mathrm{P}}{2} \frac{\mathrm{L}_{\mathrm{m}}}{\mathrm{L}_{\mathrm{r}}} \psi_{\mathrm{dr}} \mathrm{i}_{\mathrm{qs}}=\mathrm{k}_{\mathrm{t}} \psi_{\mathrm{dr}}^{\mathrm{e}} \mathrm{I}_{\mathrm{qs}}^{\mathrm{e}}
$$


Eq. (21) is similar to that of the separately excited $\mathrm{dc}$ motor and denotes that the torque is proportional to the quadrature component of the stator current $\left(\mathrm{I}_{\mathrm{qs}}^{\mathrm{e}}\right)$ if the flux direct axis component of rotor flux ( $\psi_{\mathrm{dr}}^{\mathrm{e}}$ ) is kept constant. This is the principle of field oriented control technique.

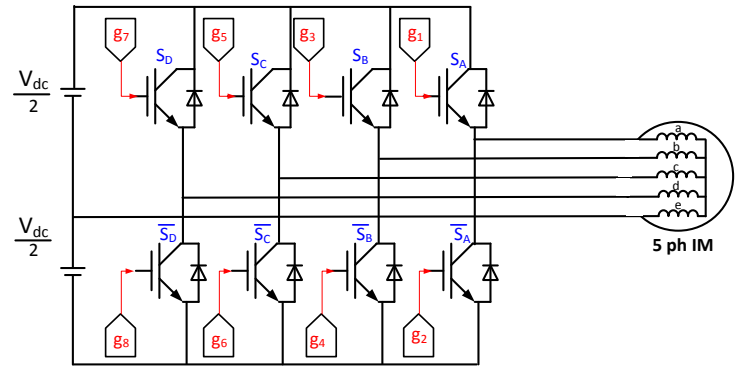

Fig. 1 Eight-switch proposed Inverter

The phase voltages of the classical ten-switch five-phase inverter fed five-phase induction motor

\section{PROPOSED EIGHT SWITCH FIVE PHASE INVERTER}

The proposed inverter has reduced switching devices compared with classical five-phase inverter which consists of ten switches. The proposed inverter consists of eight switches as shown in Fig. 1.

are introduced as a function of switching logic $\mathrm{NA}, \mathrm{NB}, \mathrm{NC}, \mathrm{ND}$ and $\mathrm{NE}$ of power switches by the following relation:

$\left[\begin{array}{l}V_{a} \\ V_{b} \\ V_{c} \\ V_{d} \\ V_{e}\end{array}\right]=\frac{V_{d c}}{5}\left[\begin{array}{ccccc}4 & -1 & -1 & -1 & -1 \\ -1 & 4 & -1 & -1 & -1 \\ -1 & -1 & 4 & -1 & -1 \\ -1 & -1 & -1 & 4 & -1 \\ -1 & -1 & -1 & -1 & 4\end{array}\right]\left[\begin{array}{c}N A \\ N B \\ N C \\ N D \\ N E\end{array}\right]$

The switching logic state may be 0 or 1 .Where, 1 is for ON state and 0 is for OFF state.

The switching table of classical ten switches fivephase inverter is given in Tab. 1.

Table 1: The switching states of ten-switch five-phase inverter

\begin{tabular}{|c|c|c|c|c|c|c|c|c|c|}
\hline NA & $\mathrm{NB}$ & $\mathrm{NC}$ & ND & $\mathrm{NE}$ & $\mathrm{V}_{\mathrm{a}}$ & $\mathrm{V}_{\mathrm{b}}$ & $\mathrm{V}_{\mathrm{c}}$ & $\mathrm{V}_{\mathrm{d}}$ & $\mathrm{V}_{\mathrm{e}}$ \\
\hline 0 & 0 & 0 & 0 & 0 & 0 & 0 & 0 & 0 & 0 \\
\hline 0 & 0 & 0 & 0 & 1 & $-0.2 V_{d c}$ & $-0.2 V_{d c}$ & $-0.2 V_{d c}$ & $-0.2 V_{d c}$ & $0.8 V_{d c}$ \\
\hline 0 & 0 & 0 & 1 & 0 & $-0.2 V_{d c}$ & $-0.2 V_{d c}$ & $-0.2 V_{d c}$ & $0.8 V_{d c}$ & $-0.2 V_{d c}$ \\
\hline 0 & 0 & 0 & 1 & 1 & $-0.4 V_{d c}$ & $-0.4 V_{d c}$ & $-0.4 V_{d c}$ & $0.6 V_{d c}$ & $0.6 V_{d c}$ \\
\hline 0 & 0 & 1 & 0 & 0 & $-0.2 V_{d c}$ & $-0.2 V_{d c}$ & $0.8 V_{d c}$ & $-0.2 V_{d c}$ & $-0.2 V_{d c}$ \\
\hline 0 & 0 & 1 & 0 & 1 & $-0.4 V_{d c}$ & $-0.4 V_{d c}$ & $0.6 V_{d c}$ & $-0.4 V_{d c}$ & $0.6 V_{d c}$ \\
\hline 0 & 0 & 1 & 1 & 0 & $-0.4 V_{d c}$ & $-0.4 V_{d c}$ & $0.6 V_{d c}$ & $0.6 V_{d c}$ & $-0.4 V_{d c}$ \\
\hline 0 & 0 & 1 & 1 & 1 & $-0.6 V_{d c}$ & $-0.6 V_{d c}$ & $0.4 V_{d c}$ & $0.4 V_{d c}$ & $0.4 V_{d c}$ \\
\hline 0 & 1 & 0 & 0 & 0 & $-0.2 V_{d c}$ & $0.8 V_{d c}$ & $-0.2 V_{d c}$ & $-0.2 V_{d c}$ & $-0.2 V_{d c}$ \\
\hline 0 & 1 & 0 & 0 & 1 & $-0.4 V_{d c}$ & $0.6 V_{d c}$ & $-0.4 V_{d c}$ & $-0.4 V_{d c}$ & $0.6 V_{d c}$ \\
\hline 0 & 1 & 0 & 1 & 0 & $-0.4 V_{d c}$ & $0.6 V_{d c}$ & $-0.4 V_{d c}$ & $0.6 V_{d c}$ & $-0.4 V_{d c}$ \\
\hline 0 & 1 & 0 & 1 & 1 & $-0.6 V_{d c}$ & $0.4 V_{d c}$ & $-0.6 V_{d c}$ & $0.4 V_{d c}$ & $0.4 V_{d c}$ \\
\hline 0 & 1 & 1 & 0 & 0 & $-0.4 V_{d c}$ & $0.6 V_{d c}$ & $0.6 V_{d c}$ & $-0.4 V_{d c}$ & $-0.4 V_{d c}$ \\
\hline 0 & 1 & 1 & 0 & 1 & $-0.6 V_{d c}$ & $0.4 V_{d c}$ & $0.4 V_{d c}$ & $-0.6 V_{d c}$ & $0.4 V_{d c}$ \\
\hline 0 & 1 & 1 & 1 & 0 & $-0.6 V_{d c}$ & $0.4 V_{d c}$ & $0.4 V_{d c}$ & $0.4 V_{d c}$ & $-0.6 V_{d c}$ \\
\hline 0 & 1 & 1 & 1 & 1 & $-0.8 V_{d c}$ & $0.2 V_{d c}$ & $0.2 V_{d c}$ & $0.2 V_{d c}$ & $0.2 V_{d c}$ \\
\hline 1 & 0 & 0 & 0 & 0 & $0.8 V_{d c}$ & $-0.2 V_{d c}$ & $-0.2 V_{d c}$ & $-0.2 V_{d c}$ & $-0.2 V_{d c}$ \\
\hline 1 & 0 & 0 & 0 & 1 & $0.6 V_{d c}$ & $-0.4 V_{d c}$ & $-0.4 V_{d c}$ & $-0.4 V_{d c}$ & $0.6 V_{d c}$ \\
\hline 1 & 0 & 0 & 1 & 0 & $0.6 V_{d c}$ & $-0.4 V_{d c}$ & $-0.4 V_{d c}$ & $0.6 V_{d c}$ & $-0.4 V_{d c}$ \\
\hline 1 & 0 & 0 & 1 & 1 & $0.4 V_{d c}$ & $-0.6 V_{d c}$ & $-0.6 V_{d c}$ & $0.4 V_{d c}$ & $0.4 V_{d c}$ \\
\hline 1 & 0 & 1 & 0 & 0 & $0.6 V_{d c}$ & $-0.4 V_{d c}$ & $0.6 V_{d c}$ & $-0.4 V_{d c}$ & $-0.4 V_{d c}$ \\
\hline 1 & 0 & 1 & 0 & 1 & $0.4 V_{d c}$ & $-0.6 V_{d c}$ & $0.4 V_{d c}$ & $-0.6 V_{d c}$ & $0.4 V_{d c}$ \\
\hline 1 & 0 & 1 & 1 & 0 & $0.4 V_{d c}$ & $-0.6 V_{d c}$ & $0.4 V_{d c}$ & $0.4 V_{d c}$ & $-0.6 V_{d c}$ \\
\hline 1 & 0 & 1 & 1 & 1 & $0.2 V_{d c}$ & $-0.8 V_{d c}$ & $0.2 V_{d c}$ & $0.2 V_{d c}$ & $0.2 V_{d c}$ \\
\hline 1 & 1 & 0 & 0 & 0 & $0.6 V_{d c}$ & $0.6 V_{d c}$ & $-0.4 V_{d c}$ & $-0.4 V_{d c}$ & $-0.4 V_{d c}$ \\
\hline 1 & 1 & 0 & 0 & 1 & $0.4 V_{d c}$ & $0.4 V_{d c}$ & $-0.6 V_{d c}$ & $-0.6 V_{d c}$ & $0.4 V_{d c}$ \\
\hline 1 & 1 & 0 & 1 & 0 & $0.4 V_{d c}$ & $0.4 V_{d c}$ & $-0.6 V_{d c}$ & $0.4 V_{d c}$ & $-0.6 V_{d c}$ \\
\hline 1 & 1 & 0 & 1 & 1 & $0.2 V_{d c}$ & $0.2 V_{d c}$ & $-0.8 V_{d c}$ & $0.2 V_{d c}$ & $0.2 V_{d c}$ \\
\hline 1 & 1 & 1 & 0 & 0 & $0.4 V_{d c}$ & $0.4 V_{d c}$ & $0.4 V_{d c}$ & $-0.6 V_{d c}$ & $-0.6 V_{d c}$ \\
\hline 1 & 1 & 1 & 0 & 1 & $0.2 V_{d c}$ & $0.2 V_{d c}$ & $0.2 V_{d c}$ & $-0.8 V_{d c}$ & $0.2 V_{d c}$ \\
\hline 1 & 1 & 1 & 1 & 0 & $0.2 V_{d c}$ & $0.2 V_{d c}$ & $0.2 V_{d c}$ & $0.2 V_{d c}$ & $-0.8 V_{d c}$ \\
\hline 1 & 1 & 1 & 1 & 1 & 0 & 0 & 0 & 0 & 0 \\
\hline
\end{tabular}


the modulated phase voltages of the proposed eight-switch five-phase inverter are introduced as a function of switching logic NA, NB, NC and ND can be defined as given in Eqs. (23) and (24).

$\left[\begin{array}{c}V_{a} \\ V_{b} \\ V_{c} \\ V_{d} \\ V_{e}\end{array}\right]=\frac{0.5 V_{d c}}{5}\left[\begin{array}{ccccc}8 & -2 & -2 & -2 & -1 \\ -2 & 8 & -2 & -2 & -1 \\ -2 & -2 & 8 & -2 & -1 \\ -2 & -2 & -2 & 8 & -1 \\ -2 & -2 & -2 & -2 & 4\end{array}\right]\left[\begin{array}{c}N A \\ N B \\ N C \\ N D \\ 1\end{array}\right]$

$$
\left[\begin{array}{l}
V_{a} \\
V_{b} \\
V_{c} \\
V_{d} \\
V_{e}
\end{array}\right]=\frac{V_{d c}}{5}\left[\begin{array}{ccccc}
4 & -1 & -1 & -1 & -1 \\
-1 & 4 & -1 & -1 & -1 \\
-1 & -1 & 4 & -1 & -1 \\
-1 & -1 & -1 & 4 & -1 \\
-1 & -1 & -1 & -1 & 4
\end{array}\right]\left[\begin{array}{c}
N A \\
N B \\
N C \\
N D \\
0.5
\end{array}\right]
$$

The switching table of eight-switch five-phase inverter is shown in Tab. 2 .

Tabel 2: The switching states of eight switch five phase inverter

\begin{tabular}{|c|c|c|c|c|c|c|c|c|}
\hline $\mathrm{NA}$ & $\mathrm{NB}$ & $\mathrm{NC}$ & $\mathrm{ND}$ & $\mathrm{V}_{\mathrm{a}}$ & $\mathrm{V}_{\mathrm{b}}$ & $\mathrm{V}_{\mathrm{c}}$ & $\mathrm{V}_{\mathrm{d}}$ & $\mathrm{V}_{\mathrm{e}}$ \\
\hline 0 & 0 & 0 & 0 & $-0.1 V_{d c}$ & $-0.1 V_{d c}$ & $-0.1 V_{d c}$ & $-0.1 V_{d c}$ & $0.4 V_{d c}$ \\
\hline 0 & 0 & 0 & 1 & $-0.3 V_{d c}$ & $-0.3 V_{d c}$ & $-0.3 V_{d c}$ & $0.7 V_{d c}$ & $0.2 V_{d c}$ \\
\hline 0 & 0 & 1 & 0 & $-0.3 V_{d c}$ & $-0.3 V_{d c}$ & $0.7 V_{d c}$ & $-0.3 V_{d c}$ & $0.2 V_{d c}$ \\
\hline 0 & 0 & 1 & 1 & $-0.5 V_{d c}$ & $-0.5 V_{d c}$ & $0.5 V_{d c}$ & $0.5 V_{d c}$ & 0 \\
\hline 0 & 1 & 0 & 0 & $-0.3 V_{d c}$ & $0.7 V_{d c}$ & $-0.3 V_{d c}$ & $-0.3 V_{d c}$ & $0.2 V_{d c}$ \\
\hline 0 & 1 & 0 & 1 & $-0.5 V_{d c}$ & $0.5 V_{d c}$ & $-0.5 V_{d c}$ & $0.5 V_{d c}$ & 0 \\
\hline 0 & 1 & 1 & 0 & $-0.5 V_{d c}$ & $0.5 V_{d c}$ & $0.5 V_{d c}$ & $-0.5 V_{d c}$ & 0 \\
\hline 0 & 1 & 1 & 1 & $-0.7 V_{d c}$ & $0.3 V_{d c}$ & $0.3 V_{d c}$ & $0.3 V_{d c}$ & $-0.2 V_{d c}$ \\
\hline 1 & 0 & 0 & 0 & $0.7 V_{d c}$ & $-0.3 V_{d c}$ & $-0.3 V_{d c}$ & $-0.3 V_{d c}$ & $0.2 V_{d c}$ \\
\hline 1 & 0 & 0 & 1 & $0.5 V_{d c}$ & $-0.5 V_{d c}$ & $-0.5 V_{d c}$ & $0.5 V_{d c}$ & 0 \\
\hline 1 & 0 & 1 & 0 & $0.5 V_{d c}$ & $-0.5 V_{d c}$ & $0.5 V_{d c}$ & $-0.5 V_{d c}$ & 0 \\
\hline 1 & 0 & 1 & 1 & $0.3 V_{d c}$ & $-0.7 V_{d c}$ & $0.3 V_{d c}$ & $0.3 V_{d c}$ & $-0.2 V_{d c}$ \\
\hline 1 & 1 & 0 & 0 & $0.5 V_{d c}$ & $0.5 V_{d c}$ & $-0.5 V_{d c}$ & $-0.5 V_{d c}$ & 0 \\
\hline 1 & 1 & 0 & 1 & $0.3 V_{d c}$ & $0.3 V_{d c}$ & $-0.7 V_{d c}$ & $0.3 V_{d c}$ & $-0.2 V_{d c}$ \\
\hline 1 & 1 & 1 & 0 & $0.3 V_{d c}$ & $0.3 V_{d c}$ & $0.3 V_{d c}$ & $-0.7 V_{d c}$ & $-0.2 V_{d c}$ \\
\hline 1 & 1 & 1 & 1 & $0.1 V_{d c}$ & $0.1 V_{d c}$ & $0.1 V_{d c}$ & $0.1 V_{d c}$ & $-0.4 V_{d c}$ \\
\hline
\end{tabular}

\section{PROPOSED INDIRECT ROTOR FIELD ORIENTED FIVE-PHASE INDUCTION MOTOR}

The principle of indirect rotor field oriented control is applied to Five-phase induction motor. The application of the vector control scheme to such arrangement is simple, and can provide fast-decoupled control of torque and flux. The description of the complete system is illustrated in Fig. 2.
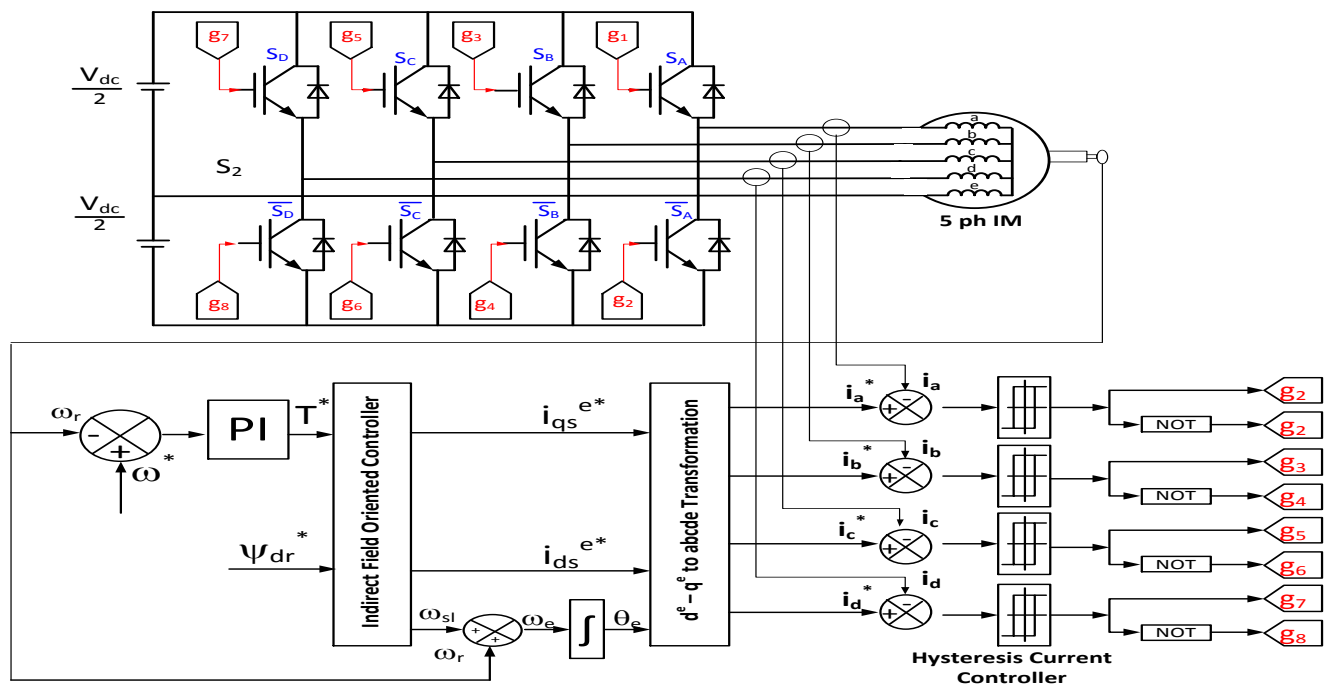

Fig. 2 Block diagram of speed control system 
In Fig.2, the motor speed, $\omega_{\mathrm{r}}$ is compared to a reference speed, $\omega^{*}$, and the error signal is processed by the PI controller, to generate the torque-component current command $\mathrm{I}_{\mathrm{qs}}{ }^{\mathrm{e} *}$ as shown in Eq. (15). The flux- component of current command $\mathrm{I}_{\mathrm{ds}}{ }^{\mathrm{e} *}$ is calculated according to adopted control strategy as given in Eq. (16). The two current command components are then transformed with the help of rotor position encoder $\left(\right.$ angle $\left.\theta_{\mathrm{e}}\right)$ to five current commands $\mathrm{i}_{\mathrm{a}}, \mathrm{i}_{\mathrm{b}}, \mathrm{i}_{\mathrm{c}}, \mathrm{i}_{\mathrm{d}}$ and $\mathrm{i}_{\mathrm{e}}$ in the stationary reference frame as define. in Eq. (20). These current commands are then compared to the actual motor currents by hysteresis current controller to generate the logic pulses for the inverter switches.

\section{SIMULATIONS AND DISCUSSIONS}

In this section, it is assumed that per-phase parameters and ratings of the 5-phaseinduction motor are the same as for the three-phase motor due to the lack of data of 5-phase motor. The parameters of the motor are listed in the Appendix. The system is developed and simulated using MatLab R2014a. Various scenarios including speed and load torque variations are presented to study the performance of the system with proposed topology of eight switch inverter and classical ten switch inverter. The results of the proposed eight-switch inverter are compared with those of classical ten switch inverter.

\subsection{SIMULATION RESULTS UNDER DIFFERENT REFERENCE SPEEDS}

In this case of loading; the load torque is maintained constant at 5 N.m and the reference speed is changed from $50 \mathrm{rad} / \mathrm{s}$ (477.4648 rpm) to $100 \mathrm{rad} / \mathrm{s}(954.9297 \mathrm{rpm})$ at $\mathrm{t}=2 \mathrm{~s}$ and then to 150 $\mathrm{rad} / \mathrm{s}(1432.4 \mathrm{rpm})$ at $\mathrm{t}=4 \mathrm{~s}$ and to $120 \mathrm{rad} / \mathrm{s}$ $(1145.9 \mathrm{rpm})$ at $\mathrm{t}=6 \mathrm{~s}$ as shown in Fig. 3 . It can be noticed that the motor response of eight switch inverter is similar to that to ten switch and the error between actual speed and motor speed is insignificant and the motor response is very fast to track reference speed. The motor phase currents are identical in both inverter techniques for lower range of speeds up to $100 \mathrm{rad} / \mathrm{s}$ as shown in Fig. 4. It has been shown that for higher speed, as shown in Fig. 5, at $150 \mathrm{rad} / \mathrm{s}$ the actual and reference current are the same for classical 10 switch inverter. But, in proposed 8 switch inverter the error between the reference and actual motor current is significant and the actual currents are non-sinusoidal and the motor peak current is higher than the one of 10 switch inverter. Therefore, the load torque of 8 switch inverter must be lower than one of 10 switch at this speed to avoid motor overheating. This a drawback of 8 switch inverter that at speeds near rated value the motor control fails to achieve field orientation as shown in Fig. $6\left(\psi_{\mathrm{qr}}\right.$ has value at speed 150 and $120 \mathrm{rad} / \mathrm{s}$ ) and motor current is higher than the 10 switch inverter. The reason of this disadvantage is that the motor voltage in 8 switch is insufficient to give rated reference flux $(0.9 \mathrm{~V} / \mathrm{rad} / \mathrm{s})$ as illustrated in Fig. 7 as $\psi_{\mathrm{dr}}$ has value lower than 0.9 at 150 and $120 \mathrm{rad} / \mathrm{s}$. The solution of this problem will be presented in sec.(5.3) in this paper. 

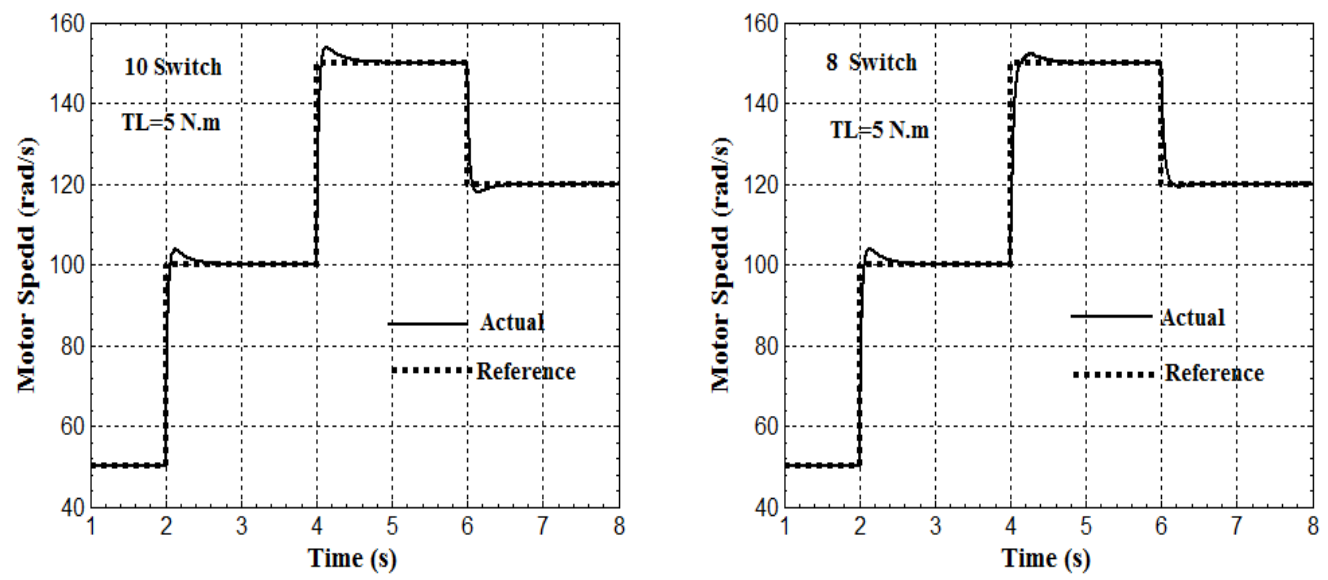

Fig. 3 Variation of motor speed with time at constant load torque of 5 N.m
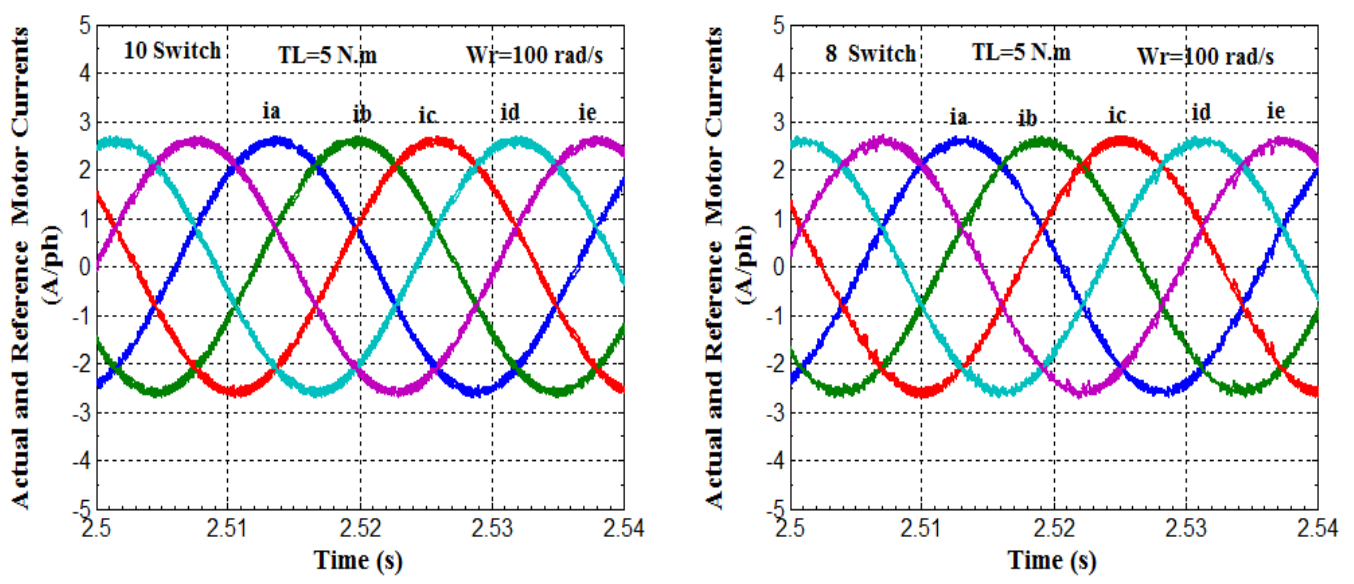

Fig. 4 Variation of actual and reference motor currents against time at $\omega_{\mathrm{r}}=100 \mathrm{rad} / \mathrm{s}$
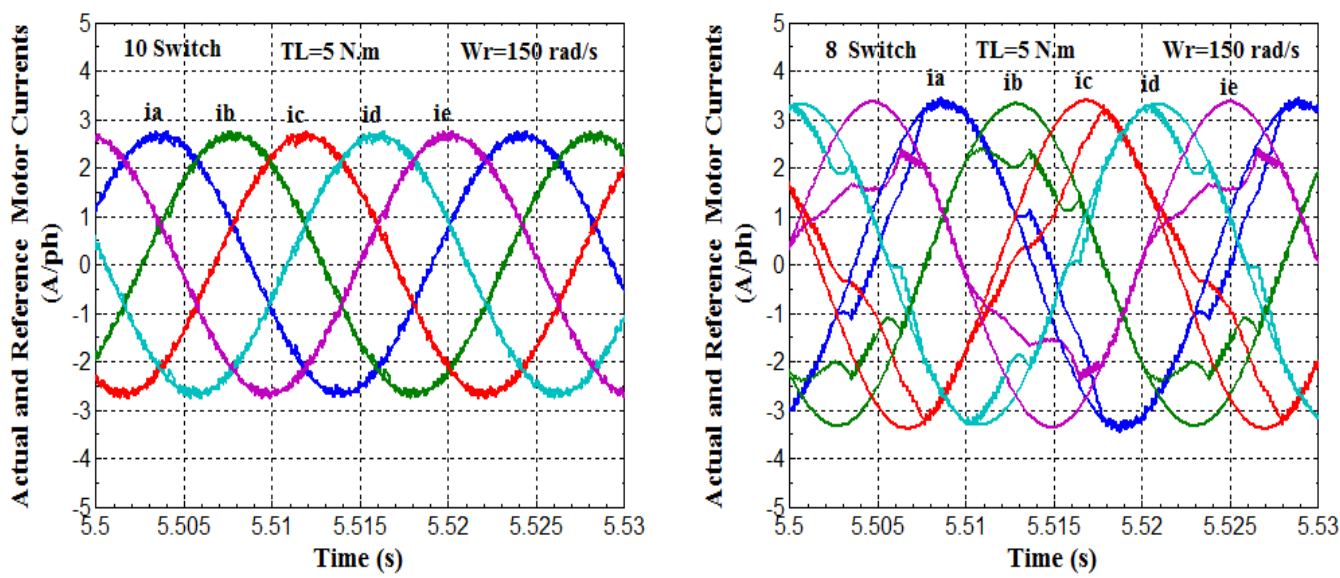

Fig. 5 Variation of actual and reference motor currents against time at $\omega_{\mathrm{r}}=150 \mathrm{rad} / \mathrm{s}$ 

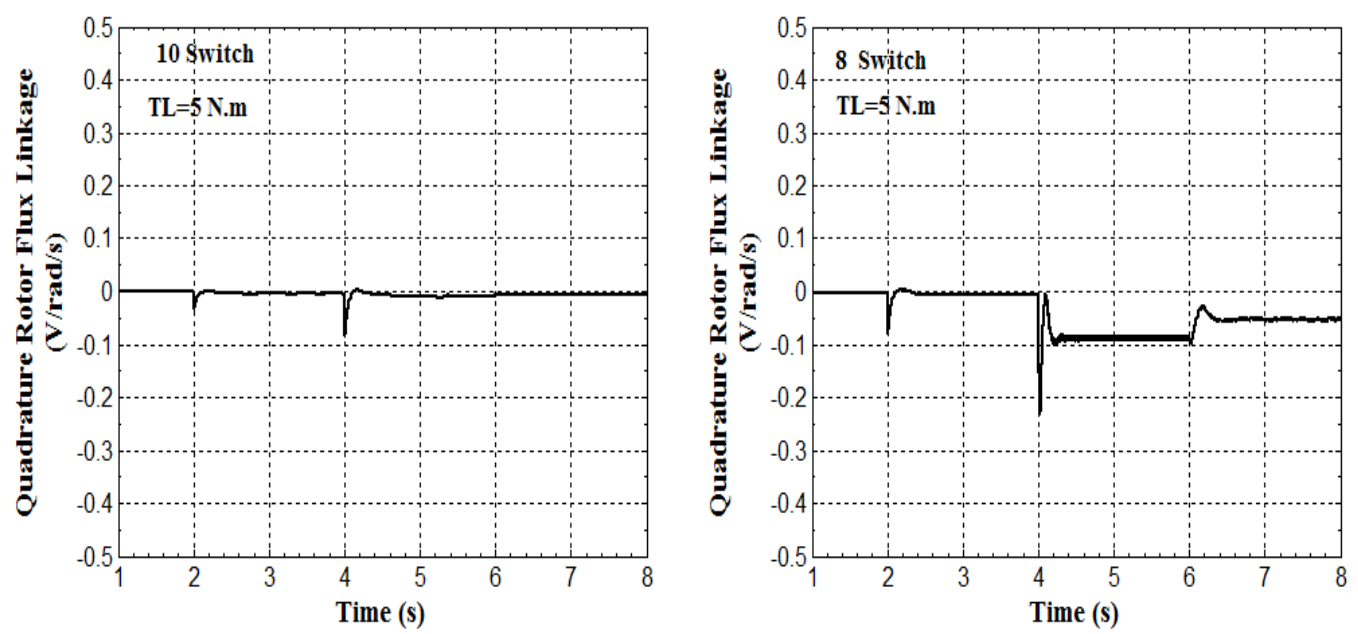

Fig. 6 Variation of quadrature rotor flux versus time at constant load torque of 5 N.m
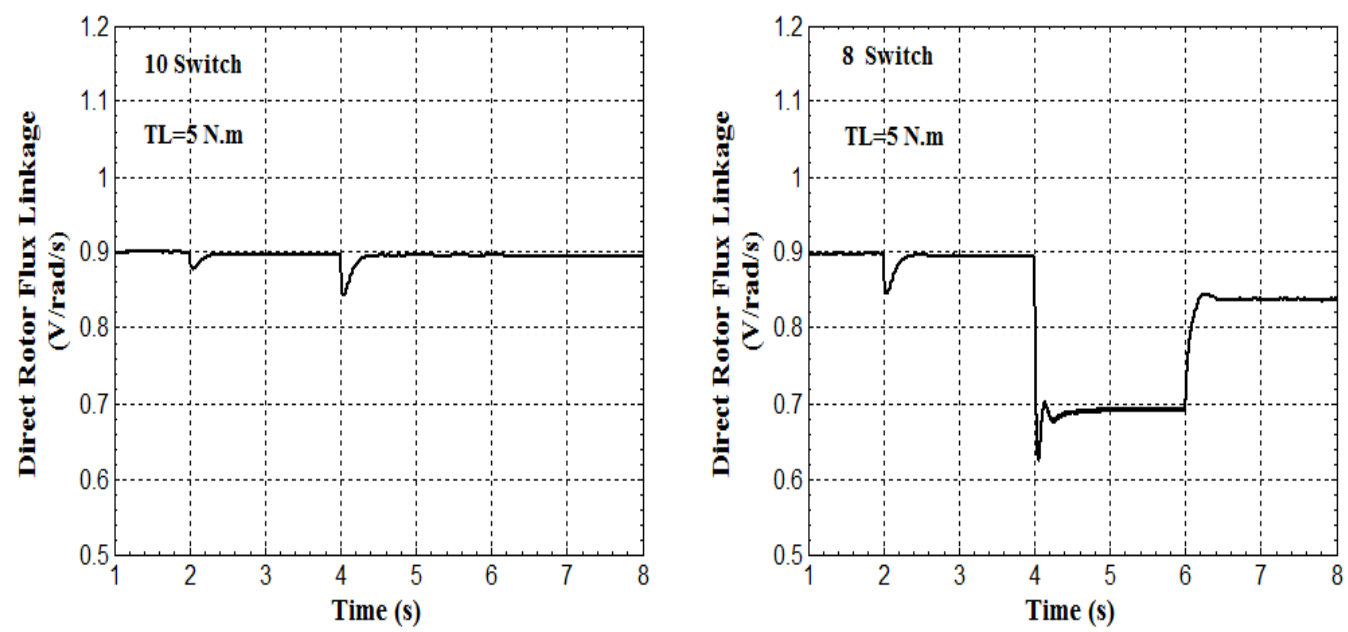

Fig. 7 Variation of direct rotor flux versus time at constant load torque of 5 N.m

\subsection{RESPONSE WITH DIFFERENT LOAD TORQUES}

In this scenario of loading; the reference speed is constant at $100 \mathrm{rad} / \mathrm{s}(954.9297 \mathrm{rpm})$ and load torque is changed from $1 \mathrm{~N} . \mathrm{m}$ to $3 \mathrm{~N} . \mathrm{m}$ at $\mathrm{t}=2 \mathrm{~s}$ and then to 7 N.m at $t=4 \mathrm{~s}$ and to 5 N.m at $\mathrm{t}=6 \mathrm{~s}$ as shown in Fig. 8.

The motor developed required reference torque at reference speed in both two inverter technique as shown in Fig. 8 and Fig. 9 respectively. The motor currents in both inverter techniques are approximately similar as illustrated in Fig. 10. This similarity in motor currents is due to the motor in both inverters achieves field orientation $\left(\psi_{\mathrm{qr}}=0\right)$ with reference flux $\left(\psi_{\mathrm{dr}}=\right.$ $0.9 \mathrm{~V} / \mathrm{rad} / \mathrm{s}$ ) as shown in Figs. 11 and 12 respectively 

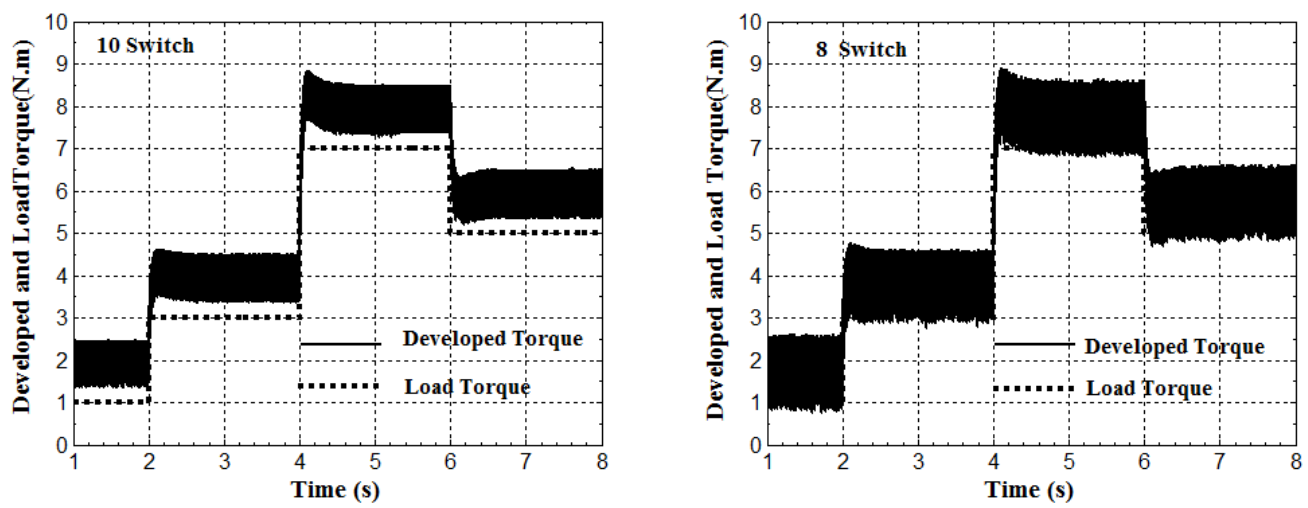

Fig. 8 Variation of developed and load torques with time at constant reference speed of $100 \mathrm{rad} / \mathrm{s}$
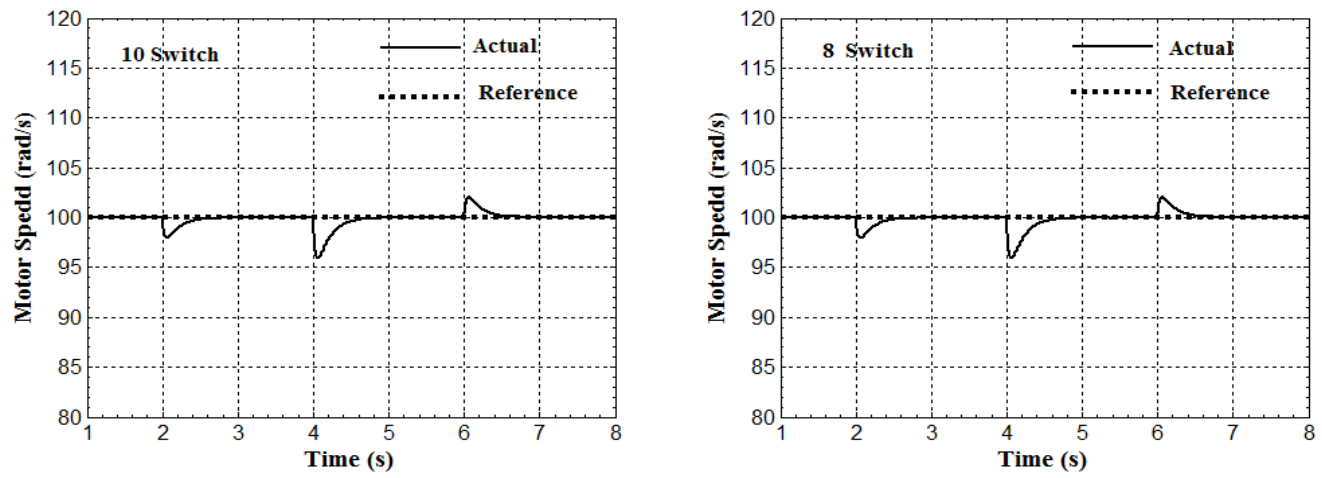

Fig. 9 Variation of motor speed versus time
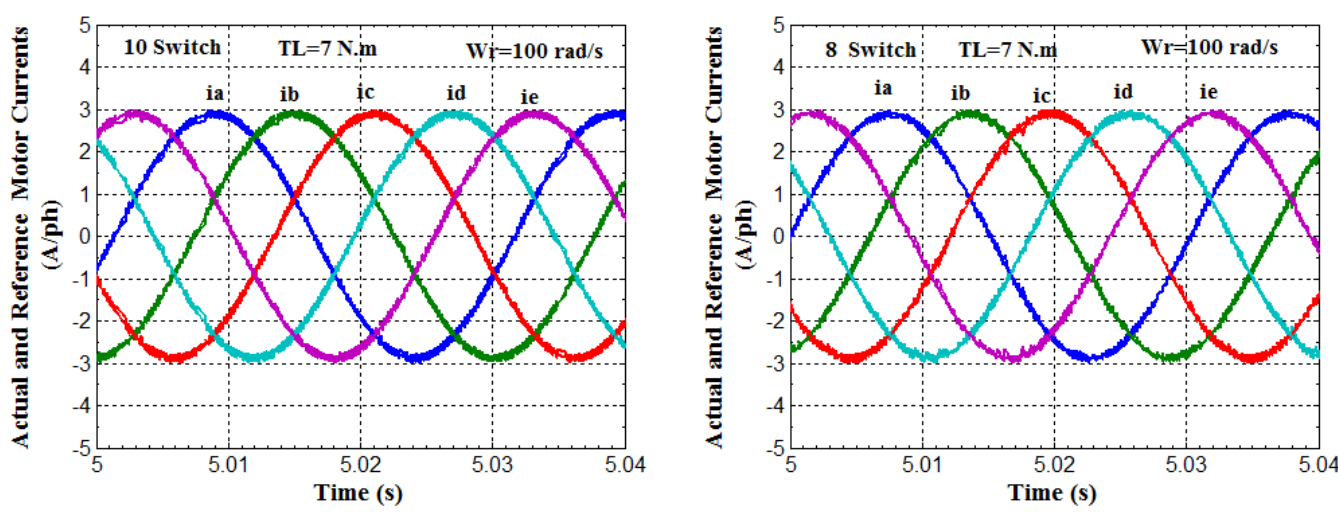

Fig. 10 Variation of actual and reference motor current against time with $\mathrm{T}_{\mathrm{L}}=7 \mathrm{~N} . \mathrm{m}$
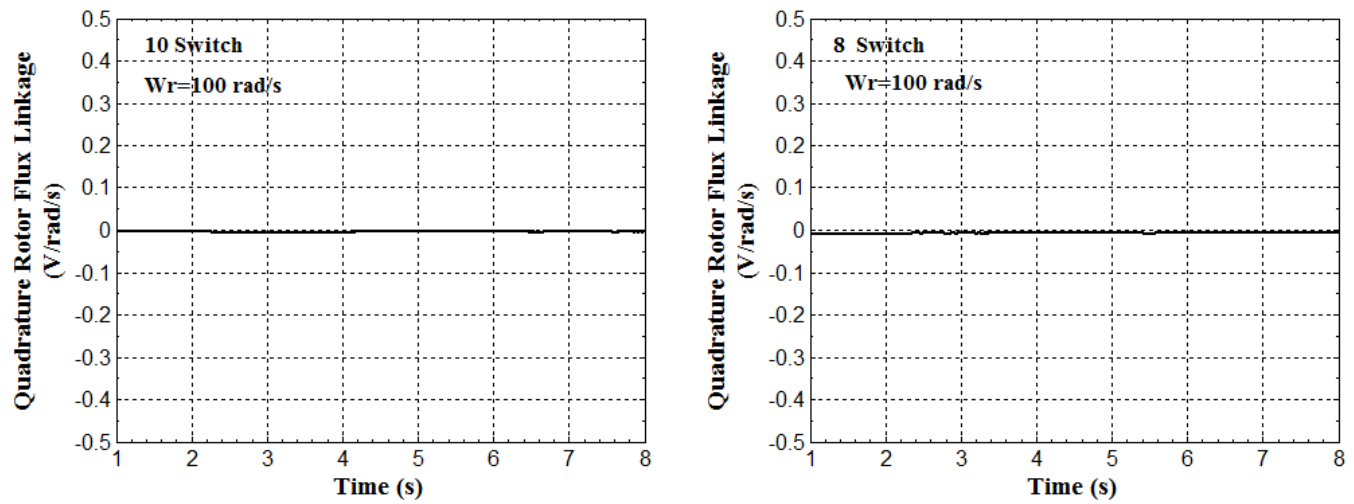

Fig. 11 Variation of quadrature rotor flux versus time 

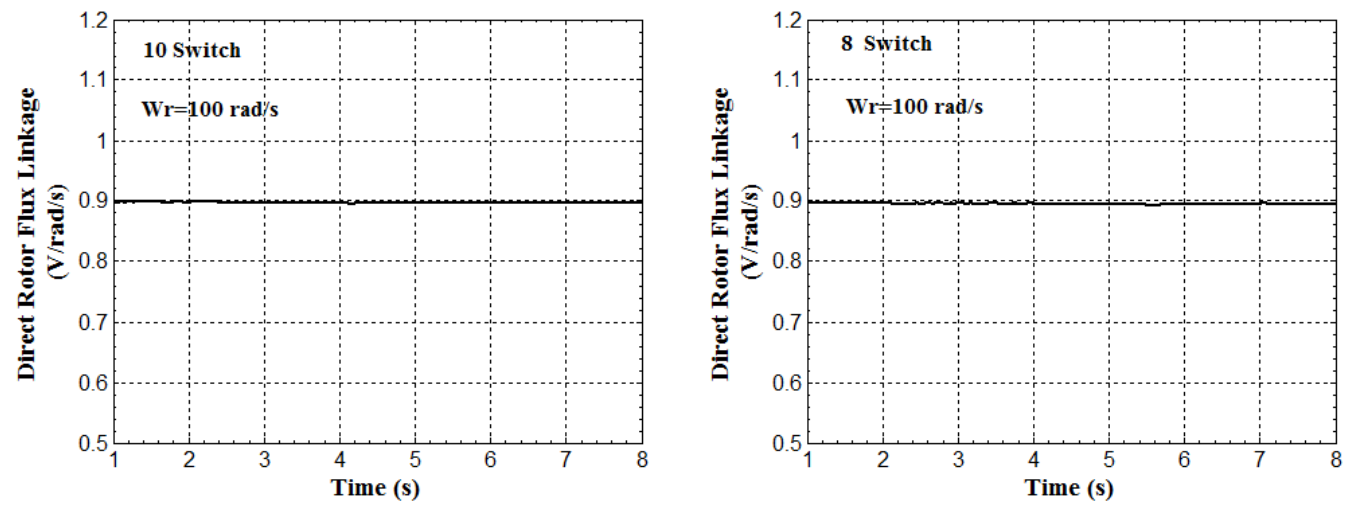

Fig. 12 Variation of direct rotor flux versus time

\subsection{RESPONSE AT A HIGHER DC VALUE}

It noticed that from above results that two techniques of inverters are similar for certain range of motor speed and load torque. But the difference between two inverters appears when the motor voltage in eight switch inverter is insufficient to develop required speed and load

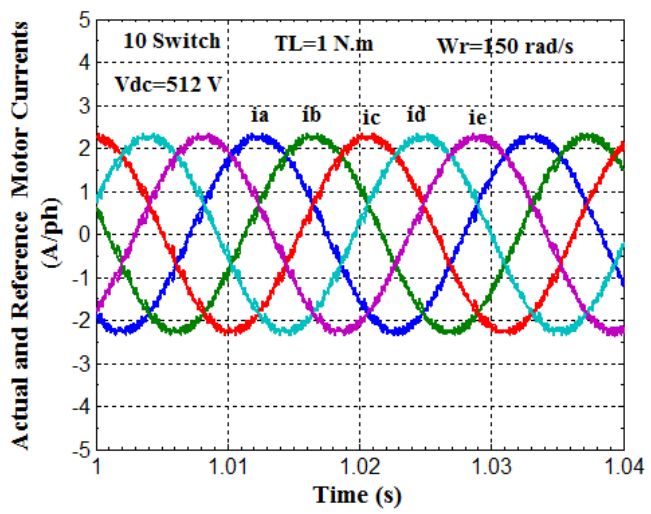

torque. This diversity can be eliminated by increasing the DC voltage of 8 switch inverter to $700 \mathrm{~V}$ instead of $512 \mathrm{~V}$ in 10 switch inverter. The motor currents in both inverters are similar at reference speed of $150 \mathrm{rad} / \mathrm{s}$ and load torque of 1 N.m and 7 N.m as shown in Figs. 13 and 14 respectively.

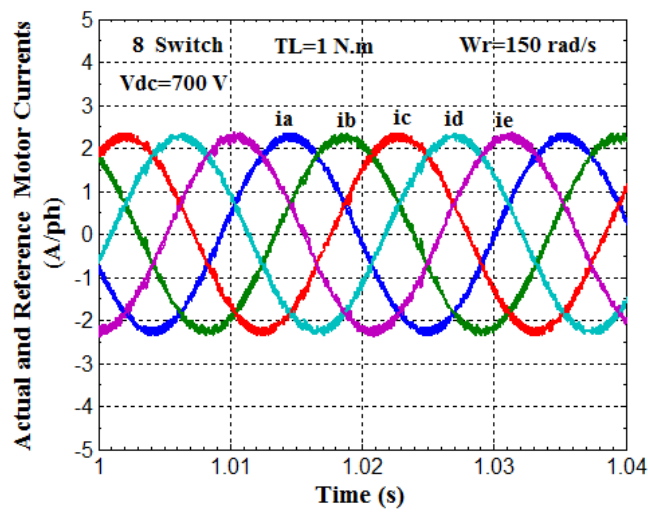

Fig. 13 Variation of motor current against time and $V_{d c}=700 \mathrm{~V}$ in 8 switch inverter at $\mathrm{T}_{\mathrm{L}}=1 \mathrm{~N}$. m
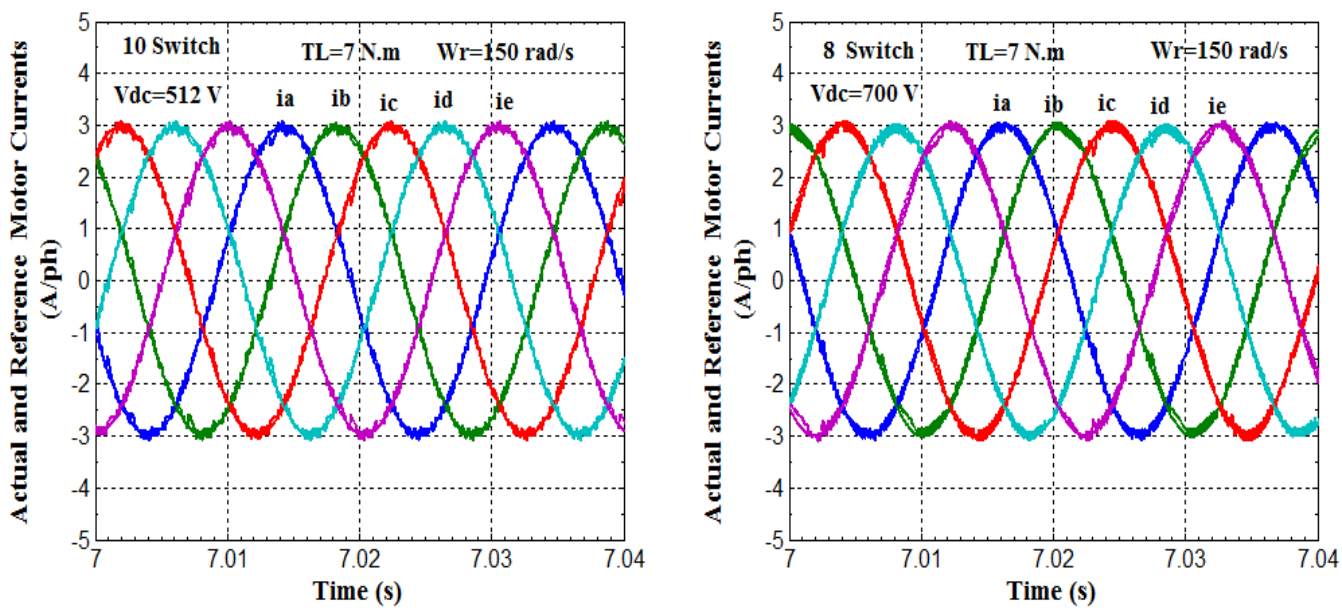

Fig. 14 Variation of motor current against time and $V_{d c}=700 \mathrm{~V}$ in 8 switch inverter at $\mathrm{T}_{\mathrm{L}}=7 \mathrm{~N}$. m 


\section{CONCLUSION}

In this paper, the performance characteristics of vector control for five phase induction motor with eight switch five phase inverter have been presented The proposed inverter reduces the number of power switches from ten to eight, and this improves the cost and reliability of the system. The system is simulated with sudden change in speed and load torque and the results ensure that the motor performance with proposed eight switch inverter is similar to those of tenswitch inverter for certain range of motor speed and load torque. The DC voltage of the proposed eight-switch inverter must be compensated to a higher value to achieve the same performance of the classical-ten switch inverter in all ranges of motor speed and load torque.

\section{REFERENCES}

[1] Levi, E., Bojoi, R., Profumo, F., Toliyat, H.A., and Williamson, S., "Multiphase induction motor drives technology status review"' IET Electric. Power Applications, vol.1 no. 4, pp. 489-516, 2007.

[2] E. Levi, "Multi-phase Electric Machines for Variable speed applications," IEEE Transactions on Industrial Electronics, vol. 55 no. 5, pp. 1893- 1909, 2008.

[3] V.S. Bharath and Gopinath Mani, "Closed Loop Analysis of Multilevel Inverter Fed Drives", International Journal of Power Electronics and Drive System (IJPEDS), vol. 4 no. 3, pp. 337342, 2014.

[4] Gnana Prakash $M$, Balamurugan $M$ and Umashankar S, "A New Multilevel Inverter with Reduced Number of Switches", International Journal of Power Electronics and Drive System (IJPEDS), vol. 5 no. 1, pp. 63-70, 2014.

[5] A.S. Abdel-Khalik, A.S. Morsy, S. Ahmed and A.M. Massoud, "Effect of Stator Winding Connection on Performance of Five-Phase Induction Machines", IEEE Transactions on Industrial Electronics, vol.61 no.1, pp.3-19, 2014.

[6] Singh G.K., "Multi-phase induction machine drive research - a survey", Electric Power Systems Research, vol. 61, pp. 139-147, 2002.

[7] S. M. Dabour and M. I. Masoud, "Open-circuit fault detection of five-phase voltage source inverters", Proceedings of the $8^{\text {th }}$ IEEE GCC Conference and Exhibition, Muscat 2015, Oman, pp.1-6.

[8] G. R. Batista, F. Salvadori, C. B. Jacobina, and I. S. Freitas, "Fault tolerant high performance drive system using six-phase induction machine", 2013 Brazilian Power Electronics, 2013, IEEE, Gramado, pp. 786-792
[9] H. Guzman, J.A. Riveros, M.J. Duran and F. Barrero, "Modeling of a five-phase induction motor drive with a faulty phase," $15^{\text {th }}$ International Power Electronics and Motion Control Conference (EPE/PEMC), 2012, IEEE, Novi Sad, pp.LS1c.3-1,LS1c.3-6.

[10] Mahmoud I. Masoud, Sherif M. Dabour, Abd El-Wahab Hassan and Essam M. Rashad, " Control of five-phase induction motor under open-circuit phase fault fed by fault tolerant VSI", $10^{\text {th }}$ International Symposium on Diagnostics for Electrical Machines, Power Electronics and Drives (SDEMPED), 2015, IEEE, Guarda, pp. 327 - 332.

[11] Ankur P. Desai and Vijay G. Bhuva, "Analysis Approach for Five Phase Two-Level Voltage Source Inverter with PWM Technique for Induction Motor Drive", International Journal for Scientific Research \& Development, vol. 1 no 3, pp. 448-492, 2015.

[12] M.M.Irfan, P.H.K.Prasad, .and P.Venugopal Rao (2010)," Simulation of Five-level Five-phase SVPWM Voltage Source Inverter", International Conference on Power Control and Embedded Systems (ICPCES), 2010, IEEE, Allahabad, pp. 1 - 5.

[13] Alberto Lega, Michele Mengoni, Giovanni Serra, Angelo Tani and Luca Zarri (2008), "General Theory of Space Vector Modulation for Five-Phase Inverters", IEEE International Symposium on Industrial Electronics, 2008, IEEE, Cambridge, pp. 237 - 244

[14] G.D. Holmes and T.A. Lipo, Pulse Width Modulation for Power Converters - Principles and Practice, IEEE Press Series on Power Engineering, John Wiley and Sons, Piscataway, NJ, USA, 2003

[15] Xu, H., Toliyat, H.A., and Petersen, L.J. , "Five-phase induction motor drives with DSPbased control system", IEEE Trans. on Power Electronics, vol. 17 no. 4, pp. 524-533, 2002.

[16] G. Renukadevi and K. Rajambal, Generalized $\mathrm{d}-\mathrm{q}$ Model of $\mathrm{n}$-Phase Induction Motor Drive", International Journal of Electrical, Computer, Energetic, Electronic and Communication Engineering, vol. 6 no. 9, pp. 66-75, 2012.

APPENDIX

Motor parameters:

\begin{tabular}{|l|l|}
\hline Rated power & $1.1 \mathrm{~kW}$ \\
\hline Rated Voltage & $220 / 380 \mathrm{~V}$ \\
\hline Rated frequency & $50 \mathrm{~Hz}$ \\
\hline Poles & 4 \\
\hline Rated voltage & $220 / 380 \mathrm{~V}$ \\
\hline Stator resistance & $7.4826 \Omega$ \\
\hline Referred rotor resistance & $3.6840 \Omega$ \\
\hline Stator leakage inductance & $0.0221 \mathrm{H}$ \\
\hline Referred rotor leakage inductance & $0.0221 \mathrm{H}$ \\
\hline mutual inductance & $0.4114 \mathrm{H}$ \\
\hline Moment of inertia & $0.02 \mathrm{Kg} . \mathrm{m}^{2}$ \\
\hline
\end{tabular}


Mahmoud M. Elkholy ; Zakaria M.S. Elbarbary “PERFORMANCE ANALYSIS OF INDI...” 